\title{
Rare earth elements compositions of the Minamidani granite, Oki Islands, Japan
}

\author{
M. SAKIYAMA ${ }^{1 *}$, M. TSUBOI ${ }^{1}$ AND K. UEDA ${ }^{1}$ \\ ${ }^{1}$ Sci. Tech., Kwansei Gakuin Univ., Sanda, Hyogo, 669-1337,
} Japan (*correspondence: fzf04842@kwansei.ac.jp)

The Oki Islands locate at $40-80 \mathrm{~km}$ north of Shimane Peninsula, southwestern Japan. It consists of major 4 islands and the Dogo Island is the largest of them. Granitic rocks in the Dogo island are divided into two types, the younger granite and the older granite. The older granite occurs concordantly with surrounding metamorphic rocks and the age is $250 \mathrm{Ma}$ [1]. The younger granite occurs as small stocks and intrudes into surrounding metamorphic rocks. The granite is named Minamidani granite [1]. The Minamidani granite consists of K-feldspar, quartz, plagioclase and small amounts of biotite [2]. K-Ar age of the granite is $19.7 \pm 0.6$ Ma [2] and the Fission track zircon age of the granite is 42-53 Ma [3]. The ages and major element compositions of the Minamidani granite has been reported [1, 2], however, whole rock chemical composition of minor elements including rare earth elements (REE) has not been reported. In this study, we analyzed trace elements and rare earth elements (REE) and discuss the petrogenesis of the granite.

Whole rock chemical compositions were measured with wavelength dispersive X-ray fluorescence analyer (WDXRF), and rare earth element (REE) compositions were measured by inductively coupled plasma mass spectrometer (ICP-MS). $\mathrm{SiO}_{2}$ contents ranges from 72.6 to 78.8 wt.\%. $\mathrm{Fe}_{2} \mathrm{O}_{3}, \mathrm{MnO}$, $\mathrm{TiO}_{2}, \mathrm{CaO}, \mathrm{P}_{2} \mathrm{O}_{5}, \mathrm{Al}_{2} \mathrm{O}_{3}, \mathrm{MgO}$ decrease with increasing $\mathrm{SiO}_{2}$. $\mathrm{K}_{2} \mathrm{O}$ and $\mathrm{Na}_{2} \mathrm{O}$ are constant. It shows a characteristic composition that $\mathrm{K}_{2} \mathrm{O}(>3.56 \%)$ is rich and $\mathrm{CaO}(<1.26 \%)$ is poor. Aluminum saturation index shows peraluminous and the relationship between $\mathrm{SiO}_{2}$ and $\mathrm{FeO} / \mathrm{MgO}$ shows tholeite characteristics. The relationship between $\mathrm{Rb}$ and $\mathrm{Y}+\mathrm{Nb}$ shows volcanic arc granite (VAG) characteristics [4]. CI chondrite normalized rare earth element pattern diagram shows enrichments in light rare earth elements (LREE) and it tends to decrease to heavy rare earth elements (HREE). The total of rare earth element concentrations are higher at the southern part of the pluton, and it may indicate that the magmatic differentiation progressed from northeastern part to the southern part of the pluton.

[1] Yamauchi et al. (2009) Geology of the Saigo district. With geological sheet map 1:50,000, Saigo, Geological Survey of Japan, AIST, 121 p. [2] Tainosho et al. (1991) Jour. Geol. Soc. Japan 97, 53-60. [3] Ohira and Tsutsui (2000) Fission Track News Letter, 13, 59-61. [4] Pearce et al. (1984) J. Petrol., 25. 956-983. 